\title{
REGULACJE KONSTYTUCYJNE DOTYCZĄCE SAMORZĄDÓW TERYTORIALNYCH NA TLE UJĘCIA HISTORYCZNEGO W POLSCE
}

\author{
Jacek Wojnicki \\ Uniwersytet Warszawski \\ Wydział Nauk Politycznych i Studiów Międzynarodowych \\ e-mail: jacekwojnicki@uw.edu.pl
}

\begin{abstract}
Streszczenie. Autor w niniejszym artykule podejmuje analizę obecnych regulacji konstytucyjnych odnoszących się do kwestii władz samorządowych na tle polskich konstytucji. Zaprezentowanie ewolucji polskiego modelu samorządności lokalnej ma służyć ukazaniu procesu formowania się instytucji i praktyki politycznej dotyczącej administracji samorządowej. Wskazano jednocześnie na spory polityczne i doktrynalne dotyczące organizacji i zasad działania polskiego samorządu szczególnie ta uwaga odnosi się do szczebla regionalnego i powiatowego.
\end{abstract}

Słowa kluczowe: konstytucja, samorząd terytorialny, decentralizacja, administracja publiczna

\section{WSTĘP}

Przedmiotem analizy będzie zagadnienie konstytucjonalizacji kwestii samorządności lokalnej w polskiej praktyce ustrojowej. Głównym obiektem zainteresowania autora pozostaje konstytucja z 1997 roku, ale w tekście - z oczywistych powodów - znajdują się odwołania do wcześniejszych aktów konstytucyjnych. Warto zauważyć, iż polska tradycja samorządowa jest osadzona w tradycji reform oświeceniowych pod koniec XVIII stulecia - z tego okresu pochodzi pierwsza ustawa samorządowa - Prawo o miastach królewskich z kwietnia 1791 r. Jak podkreślają badacze epoki, jedną z ważniejszych reform Sejmu Czteroletniego (zwanego również Sejmem Wielkim) było powołanie lokalnych organów administracji państwowej o charakterze samorządowym - tzw. komisji porządkowych [Szcząska 1990: 76]. Podkreślić jednocześnie należy, iż regulacje ustawy Prawo o miastach królewskich włączono do porządku konstytucyjnego, co sytuowało Polskę w czołówce państw ówczesnej Europy. Podobna regulacja znalazła się 
w pierwszej konstytucji rewolucyjnej Francji z 3 września 1791 r. [Konstytucja 3 maja 1791..., 30; Ajnenkiel 2001: 46]. W tym miejscu warto zaakcentować znaczenie Konstytucji Księstwa Warszawskiego z lipca 1807 r. nadanej przez cesarza Napoleona. Artykuły 64-68 przywoływanego dokumentu wskazywały - jak podkreślają badacze epoki - znaczną recepcję instytucji i przepisów francuskich. W tym zakresie jednakże występowała największa rozbieżność pomiędzy regulacjami konstytucyjnymi a praktyką polityczną Księstwa Warszawskiego [Kallas 1990: 136]. Z kolei okres braku niepodległości państwowości polskiej do listopada 1918 r. spowodował możliwość czerpania z zachodnich rozwiązań ustrojowych odnoszących się do władztwa samorządowego - vide: model francuski w okresie Księstwa Warszawskiego, pruski i austriacki w okresie zaborów. Należy wspomnieć o modelu rosyjskim w Kongresówce, który jednak stanowił znaczny regres w stosunku do modeli zaprezentowanych uprzednio. Możliwość aplikacji rozwiązań obcych państw należy zapisać jako pozytywny element kształtowania się polskich doświadczeń samorządowych [Witkowski 2007: 171; Wójcik 1999: 77].

\section{ROZWINIĘCIE}

Po 1918 roku, czyli odzyskaniu niepodległego bytu państwowego przez Polskę, zdemokratyzowano zasady działalności oraz struktur organizacyjnych samorządu na szczeblu gminnym i powiatowym. Zasadę domniemania kompetencji samorządu zastąpiono zasadą domniemania kompetencji władz administracji ogólnej (szczególna rola w przedmiotowym zakresie przypadła staroście). Uczyniono je uprawnionymi do działania w kwestiach niezastrzeżonych dla jednostek samorządowych [Szreniawski 1994: 133].

Modele polskiego samorządu lokalnego i regionalnego formowały się zasadniczo podczas dwóch okresów historycznych - II i III RP. Przy czym należy wskazać na różne formacje ustrojowe w pierwszym wskazanym okresie - model parlamentarno-gabinetowy do 1926 r. oraz modyfikacja ustrojowa po zamachu majowym. Objęcie władzy w państwie przez sanację wpłynęło na postrzeganie idei samorządności terytorialnej, co znalazło swój wyraz w regulacjach ustawy scaleniowej z marca 1933 r. oraz konstytucji kwietniowej [Samorzad terytorialny w Polsce... 2000, 189]. Samorząd lokalny zniesiony de facto po lipcu 1944 roku, a de iure w marcu 1950 roku powrócił do dyskursu politycznego podczas okresu tzw. karnawału solidarnościowego 1980-1981. Wprowadzenie stanu wojennego przytłumiło te prace, które przeniosły się do ośrodków akademickich i placówek badawczych [Ochendowski 1994: 163].

Na podstawie regulacji Konstytucji marcowej jednostki samorządowe obejmowały terytorium jednostek podstawowego podziału administracyjnego państwa. Decyzje dotyczące samorządu były podejmowane przez organy obieralne. Jednostkom samorządowym przyznano zarówno osobowość cywilno-prawną, jak i publiczno-prawną. Do cech charakterystycznych zarówno na poziomie powia- 
towym, jak i wojewódzkim należało współdziałanie organów wykonawczych samorządu z organami administracji ogólnej [Kallas 2007: 391]. Warto przywołać w tym miejscu fakt, iż Konstytucja marcowa nie regulowała kwestii wyborów lokalnych. Propozycję zgłoszoną przez PPS i PSL „Wyzwolenie” odnoszącą się do zastosowania w przedmiotowym zakresie 5 przymiotników wyborczych odrzucono w głosowaniu (168 głosów za, przy 177 przeciwko). Odrzucono również wnioski poselskie dotyczące konstytucyjnie zdefiniowanej jawności obrad sejmików i rad [Krukowski 1990: 98]. Jak przywołuje Zbigniew Leoński, Konstytucja marcowa postulowała wprowadzenie szerokich kompetencji władzom lokalnym, jednakże w szczegółowych regulacjach odsyłała do aktu normatywnego rangi ustawowej. Powyższą ustawę uchwalono dopiero po 12 latach w innej rzeczywistości polityczno-ustrojowej [Leoński 1990: 2]. Rozwinięcie powyższej myśli znajdujemy u Andrzeja Piekary, który deklarował, iż wartości i cele będące inspiracją dla twórców ustawy konstytucyjnej z marca 1921 roku, wzbogacone rozwojem polskiej myśli prawno-politycznej w okresie II Rzeczypospolitej stanowiły przesłanki dla badań nad myślą samorządową w okresie lat siedemdziesiątych i osiemdziesiątych XX wieku [Samorząd terytorialny i rozwój... 1992: 10]. Faktem jest, iż okres 1918-1939 był jedynym czasem, gdy formował się polski model samorządności lokalnej. Stanowiło to ważkie doświadczenie nie tylko teoretycznej podbudowy, lecz także miało wymiar praktyczny. Jak zaznaczył Jerzy Boć, Konstytucja marcowa uznała, iż „ustrój Polski opiera się na zasadzie szerokiego samorządu terytorialnego, a w dziedzinie administracji ma charakter autonomiczny. Jednakże administracja powiatowa działa w sposób sprawny po reformie samorządowej w marcu 1933 roku" [Powiat 2001: 13]. Stanisław Wykrętowicz zaakcentował, iż wprowadzenie w życie ogólnych regulacji konstytucyjnych z marca 1921 roku nie było rzeczą prostą, ponieważ ówczesne doświadczenia samorządowe w poszczególnych zaborach były zdywersyfikowane. W takim przypadku wypracowanie jednolitego modelu samorządowego w państwie polskim wymagało kilku lat studiów i analiz naukowych [Samorzad w Polsce... 2004: 30]. Proces ustawodawczy przedłużył się, ponieważ po drodze miał miejsce zamach majowy, a nowy obóz rządzący posiadał inną filozofię działania władz lokalnych. Bogdan Dolnicki przypomniał, iż rok 1926 przyniósł zwycięstwo koncepcji „silnej władzy wykonawczej”. Kluczowy ciężar władzy państwowej przenoszono z organów kolegialnych, które zazwyczaj pochodziły z wyborów, na organy monokratyczne, powoływane w drodze mianowania [Dolnicki 1999: 316].

Odnośnie do konstytucjonalizacji samorządności terytorialnej należy wskazać, iż Konstytucja marcowa posiadała pięć artykułów (art. 65, 66, 67, 69 i 70) odnoszących się do zagadnienia władz lokalnych. Umieszczono je w rozdziale trzecim konstytucji - Władza wykonawcza [Ajnenkiel 2001: 175; Konstytucje polskie... 1999: 44]. Z kolei w Konstytucji kwietniowej znajdujemy rozdział dziesiąty - Administracja publiczna - a w nim ustrojodawca pomieścił trzy artykuły odnoszące się do kwestii samorządności lokalnej: art. 72, 73 oraz 75 [Konstytucje polskie... 1999: 83]. Warto w tym miejscu odwołać się do zdania Andrzeja Ajnenkiela, który 
zauważał, że „w sposób mniej konkretny zajmował się niźli czyniła to Konstytucja Marcowa zasadami organizacji administracji i samorządu. Zniknęły postanowienia odnoszące się do struktury wewnętrznej organów administracyjnych i samorządu, a odnoszące się do samorządu terytorialnego zostały sformułowane tak, jak gdyby dopiero ta konstytucja go powoływała" [Ajnenkiel 2001: 222].

Przełom w najnowszych dziejach polskiego samorządu przyniosły wybory tzw. kontraktowe do Sejmu i Senatu w czerwcu 1989 roku i powołanie rządu kierowanego przez Tadeusza Mazowieckiego. W tym gabinecie funkcję pełnomocnika ds. reformy samorządowej powierzono Jerzemu Regulskiemu. Owocem wysiłków jego zespołu oraz Komisji Senackiej I kadencji było przygotowanie ustaw marcowych odnoszących się do restytucji samorządności na szczeblu podstawowym, czyli gminnym. Warto przywołać słowa Jerzego Regulskiego, współtwórcy polskiego modelu władz samorządowych w latach 90. XX wieku: „koncepcja samorządu kształtowała się w latach 80 . na podstawie tego, co wiedzieliśmy, o czym myśleliśmy i co uważaliśmy za najważniejsze. Zasadniczym dla nas wówczas problemem było to, jak przeprowadzić zmiany, i jak później zapewnić funkcjonowanie samorządowi, wbrew różnym naciskom. Wierzyliśmy, że jedyną siłą zdolną do przeciwstawienia się dawnej administracji i partii było społeczeństwo. I stąd postulowaliśmy, a potem wprowadziliśmy daleko idącą autonomię władz lokalnych" [Regulski, Kulesza 2009: 144].

W konstytucji konstytucjonalizacja reguł władz samorządowych nastąpiła po nowelizacji ustawy zasadniczej 8 marca 1990 r., gdy usunięto regulacje odnoszące się do systemu rad narodowych inkorpowanego do polskiego systemu prawnego w 1944 r. Jak wspominał Jerzy Regulski, ,ustawa samorządowa powstała w kilka tygodni. Było to możliwe, gdyż istniał już poważny dorobek i konkretne projekty, nie tylko w wyniku naszych dawnych wieloletnich badań, ale również dzięki działalności różnych środowisk, przede wszystkim krakowskiego Centrum Inicjatyw Ustawodawczych i katowickiej grupy profesorów Karola Podgórskiego i Waleriana Pańki” [Regulski 2000: 78]. Należy również przywołać, iż kwestie samorządności lokalnej znalazły odwołanie w Małej Konstytucji z października 1992 r. Była to najdłuższa z trzech obowiązujących w Polsce tzw. Małych Konstytucji (tzn. 1919. 1947 oraz 1992). Liczyła 78 artykułów pomieszczonych w pięciu rozdziałach - rozdział ostatni nosił tytuł Samorzad terytorialny. Znaczenie samorządności uznane przez ustrojodawcę znalazło swój wyraz w tytule aktu konstytucyjnego - Ustawa Konstytucyjna o wzajemnych stosunkach między władzą ustawodawczą i wykonawczą Rzeczypospolitej Polskiej i o samorządzie terytorialnym [Ajnenkiel 2001: 357; Konstytucje polskie... 1999: 395]. Kwestie samorządności lokalnej (i potencjalnej - regionalnej) stanowiły obiekt licznych i zawziętych sporów zarówno pomiędzy teoretykami, jak i aktywnymi uczestnikami sceny politycznej. Spory obejmowały zagadnienia zadań i finansów władz lokalnych, problem regionalizacji państwa i autonomii regionalnej. Spory obejmowały również kwestie kształtu szczebla ponadgminnego, występowania jednostek pomocniczych oraz regulacji ordynacji wyborczej [Radomski 2017: 198]. 
Należy zwrócić uwagę, iż regulacje odnoszące się do samorządności lokalnej były przedmiotem sporu podczas prac Komisji Konstytucyjnej w latach 1993-1996. Przesłanką był spór pomiędzy ugrupowaniami parlamentarnymi dotyczący przyszłego kształtu ustrojowego władz lokalnych (i ewentualnie regionalnych). Warto w tym kontekście przywołać słowa Tadeusza Mazowieckiego: „kompromisem była sprawa powiatów, gdzie »powiat« był słowem zakazanym dla PSL. Doszliśmy do porozumienia, mimo że został nazwany przez zwolenników reformy administracyjnej »zgniłym kompromisem « (prof. Michał Kulesza). Dziś właśnie dzięki temu kompromisowi można było tę reformę realizować. PSL nie chciał słyszeć o powiecie, więc użyto słów »Inne jednostki samorządu lokalnego i regionalnego «" [Bujak 2017: 159]. Powyższą wypowiedź potwierdzają słowa jednego z prominentnych polityków lewicy postkomunistycznej Marka Borowskiego: „Ten rozdział samorządowy był dość ważny. Jeżeli możemy tutaj mówić o koalicjach, to była jakaś koalicja w kwestii samorządowej. Można powiedzieć, UP znowu z PSL-em. Oni nie chcieli reformy powiatowej, w związku z czym nie chcieli żadnego zapisu, który by na to wskazywał. UW, która chciała reformy powiatowej i regionalnej, chciała, żeby były zapisy, który do tego zobowiązują. My, owszem byliśmy za reformą powiatową i za regionalną. Ale w pewnym momencie doszło do tego, że tej konstytucji, mówiąc krótko, by nie było. A poza tym my nie bardzo jeszcze byliśmy pewni co do kształtu tej reformy powiatowej. W związku z czym chcieliśmy, żeby też jakaś furtka została. To stąd ten zapis, który jest takim zapisem kompromisem" [Bujak 2017: 170]. Walkę o regulacje samorządowe potwierdzają słowa ówczesnego posła ludowców Aleksandra Bentkowskiego: „od początku byliśmy przeciwni powiatom, a UW i SLD wyraźnie forsowały powiaty. Chciały, aby powiaty zostały wpisane do konstytucji - »samorząd terytorialny dzieli się na samorząd gminny, powiatowy i samorząd wojewódzki«. Z tym, że szczebel wojewódzki miał być państwowo-samorządowy. My powiedzieliśmy SLD, że jeżeli nie zgodzą się na wykreślenie tego z konstytucji, to koalicja się rozpadnie, i SLD się na to zgodziło, i powiaty nie zostały zapisane w konstytucji - pozostała otwarta formuła, a rozstrzygnięcie pozostawiliśmy na czas późniejszy mając nadzieję, że rozsądek zwycięży" [Bujak 2017: 231].

Regulacje konstytucyjne odnoszące się do kwestii samorządności lokalnej w obecnie obowiązującej konstytucji należą do najbardziej szczegółowych w polskiej historii konstytucjonalizmu. Obejmują dwanaście artykułów rozmieszczonych w dwóch rozdziałach - pierwszym (Rzeczpospolita) oraz siódmym (Samorząd terytorialny). Jak podkreślił Bogdan Dolnicki, sposób regulacji z 1997 r. był nieznany poprzednim aktom konstytucyjnym, a szczególnie istotne było zaliczenie zasady samorządności i decentralizacji władzy publicznej do naczelnych zasad ustrojowych [Dolnicki 2009: 53]. Artykuł 15 deklaruje zasadę decentralizacji władzy państwowej, na podstawie której funkcjonują w Polsce samorządy lokalne i zawodowe. Jak zwrócił uwagę Bogusław Banaszak, decentralizacja oznacza traktowanie samorządu terytorialnego jako jednej z form udziału obywateli w procesie rządzenia państwem, instytucję, której zadaniem jest służba budowie demokracji oddolnej [Banaszak 2004: 566]. 
Ustrojodawca jednocześnie deklaruje to, na jakich zasadach mogą być tworzone jednostki terytorialne. Wymieniono dwie podstawowe zasady - uwzględnianie więzi społecznych, gospodarczych oraz kulturalnych oraz zdolność do wykonywania zadań publicznych (art. 15). Warto w tym miejscu odnotować, iż żadna wcześniejsza regulacja konstytucyjna nie odnosiła się do powyższych kwestii. $\mathrm{Z}$ kolei istotny dla organizacji oraz miejsca samorządu w strukturze państwa jest artykuł 16. Stanowi on, iż „ogół mieszkańców jednostek zasadniczego podziału terytorialnego stanowi z mocy prawa wspólnoty samorządowe”. W powyższym kontekście należy rozumieć, iż wspólnota samorządowa występuje na trzech szczeblach (od 1 stycznia 1999 roku) - gminnym, powiatowym i województwa. Eugeniusz Zieliński, analizując kwestie administracji publicznej, zwrócił uwagę, iż jej podstawą jest samorząd terytorialny. Samorząd ten działa we wszystkich jednostkach zasadniczego podziału terytorialnego kraju [Zieliński 2013: 259].

Istotna jest również konstytucyjna definicja samorządności terytorialnej, która znajduje się również w omawianym artykule. Ustrojodawca deklaruje, iż „samorząd terytorialny uczestniczy w sprawowaniu władzy publicznej”. W dalszej części przepisów konstytucyjnych spotykamy doprecyzowanie przywołanej definicji samorządności. W konstytucji znajduje się deklaracja, iż „przysługującą mu w ramach ustaw istotną część zadań publicznych samorząd wykonuje w imieniu własnym i na własną odpowiedzialność" (art. 16 ust. 2).

Kwestiom samorządności poświęcono - jak już wspomniano uprzednio rozdział siódmy zawierający dziesięć artykułów (art. 163-172). Jak podkreśliła Barbara Zawadzka, ujęcie regulacji samorządowych w siódmym rozdziale w pełni odpowiada założeniom doktryny, iż istota samorządu wyraża się w sprawowaniu władzy publicznej [Zawadzka 1998: 208]. Wspomniane regulacje należy odnotować jako dość szczegółowe, ale jednocześnie niedokończone. O powyższym decydował zapewne rozdźwięk wśród ówczesnych ugrupowań parlamentarnych (i to nawet tych stanowiących nieformalną koalicję konstytucyjną) odnośnie do przyszłego kształtu ustrojowego samorządu lokalnego i regionalnego. Warto wspomnieć, iż prace nad konstytucją toczyły się do 1997 r., a reforma powiatowa i regionalna miała miejsce rok później, wiosną 1998 r., podczas rządów następnej koalicji rządowej - opracowała i wdrożyła ją Rada Ministrów kierowana przez Jerzego Buzka. W sejmowym exposé premiera J. Buzka wygłoszonym na posiedzeniu 10 listopada 1997 roku znalazła się deklaracja: ,szliśmy po władzę dla ludzi, po to, by ją ludziom oddać, by obywatele i społeczności lokalne wzięły tę część władzy, którą potrafią wykorzystać lepiej od państwa. By państwo - ograniczone w swoich wpływach - stało się silniejsze niż dziś w dziedzinach, w których nikt go nie zastąpi, choćby w kwestii gwarantowania bezpieczeństwa narodowi i przeciwdziałania kataklizmom. [...] Reforma samorządowa i towarzysząca jej naprawa finansów publicznych, prywatyzacja, reprywatyzacja i upowszechnienie własności stanowią fundament dla skutecznej realizacji reformy systemu edukacji, służby zdrowia, pomocy społecznej i systemu emerytalno-rentowego" [Buzek 1998: 938]. Stąd wynika kwestia, iż interpretacja niektórych regulacji konstytucyjnych 
po wprowadzeniu szczebla powiatowego i wojewódzkiego wygląda inaczej niż w momencie tworzenia przepisów konstytucyjnych w stanie prawnym 1997 roku.

Istotną zasadą ustrojową, którą polski ustrojodawca wprowadził do porządku konstytucyjnego, jest zasada pomocniczości (subsydiarności). Ewa Popławska podkreśliła, iż rozwinięcie zasady subsydiarności znajdujemy w regulacjach artykułu 163 konstytucji, które ustanawiają domniemanie kompetencji do wykonywania zasad publicznych na rzecz władz lokalnych [Popławska 1998: 200]. Należy podkreślić, iż w regulacjach konstytucyjnych można dostrzec dwa domniemania kompetencji zgodne z przywołaną zasadą pomocniczości. Pierwsza występuje $\mathrm{w}$ artykule 163 , a druga w następnym - 164. Pierwsza pozwala na domniemanie pierwszeństwa władz lokalnych i regionalnych w wykonywaniu zadań publicznych przed administracją rządową i państwową. Natomiast istotnym uzupełnieniem powyższej regulacji jest występujące w konstytucji domniemanie pierwszeństwa gminy jako szczebla podstawowego w wykonywaniu zadań przez administrację samorządową (art. 163 i 164).

Ze względu na to, że - jak stwierdzono powyżej - w momencie uchwalania konstytucji nie był rozstrzygnięty spór odnoszący się do struktury organizacyjnej polskiego modelu samorządności, zapisano, iż podstawową jednostką samorządu terytorialnego jest szczebel gminny. Dopuszczono natomiast tworzenie - na mocy regulacji ustawowych - innych szczebli samorządów lokalnych i regionalnych. Powyższe regulacje konstytucyjne przynoszą ze sobą dwie istotne konsekwencje. Po pierwsze, tylko szczebel gminny posiada swoją konstytucjonalizację na gruncie polskiego prawa ustrojowego. Po drugie, korzystając z regulacji art. 164 ust. 2 wprowadzono w 1998 r. nowe szczeble władz lokalnych (Ustawa o samorządzie powiatowym z 5 czerwca 1998 r.) oraz władz regionalnych (Ustawa o samorządzie województwa z 5 czerwca 1998 r.). Pozycja ustrojowa szczebla gminnego jest zatem mocniejsza, bo ewentualna zmiana w szczeblu podstawowym władz lokalnych wymaga w przedmiotowym zakresie zmiany konstytucji. Takiego obostrzenia nie ma natomiast w przypadku samorządu powiatowego ani szczebla regionalnego (województwa samorządowego) [Bukowski, Jędrzejewski, Rączka 2013: 55].

Ważnym aspektem autonomii samorządności terytorialnej jest jej aspekt prawny. Został on przez polskiego ustrojodawcę - w sposób bardzo czytelny, a zarazem zwarty - określony w artykule 165 . Zapisano w nim, iż jednostki samorządu terytorialnego posiadają osobowość prawną. Jej uzupełnieniem jest wyposażenie władz samorządowych w prawo własności i inne prawa majątkowe. Jednocześnie ustrojodawca wyposaża samorząd terytorialny w prawo skargi do sądów administracyjnych w przypadku działań państwa naruszających ich samodzielność (art. 165). Jak zauważył Bogdan Dolnicki, osobowość prawna nie została wymieniona w Europejskiej Karcie Samorządu Lokalnego, mimo to znacząco wzmacnia ona samodzielność władz lokalnych oraz swobodę wyboru form działania jednostek samorządowych (zarówno tych administracyjnoprawnych, jak i cywilnoprawnych) [Dolnicki 2009: 54]. 
Konstytucja w art. 166 definiuje zadania realizowane przez polskie władze lokalne i regionalne. Wyróżnia - znane już uprzednio - zadania własne i zadania zlecone. Pierwsze z nich są definiowane jako „zadania publiczne służące zaspokajaniu potrzeb wspólnoty samorządowej”. Z kolei do zadań zleconych należą ,inne zadania publiczne zlecone jednostkom samorządu terytorialnego w przypadku uzasadnionych potrzeb państwa" (art. 166). Jednocześnie ustrojodawca precyzuje, iż na gruncie regulacji ustawowych zostaną uregulowane kwestie trybu przekazywania i sposobu wykonywania zadań zleconych przez państwo (art. 166). W kontekście zadań samorządów terytorialnych Bogdan Dolnicki podkreślił problem rozdziału tych zadań i kompetencji pomiędzy poszczególne szczeble administracji samorządowej. Istnieją bowiem zadania lokalne, a ich odbiorcą jest mieszkaniec określonej wspólnoty lokalnej. Polegają one na świadczeniu usług o charakterze powszechnym. Zadania z powyższego katalogu zazwyczaj są świadczone na dwóch szczeblach - administracji gminnej (jako szczebla podstawowego) i powiatowej [Dolnicki 2009: 59].

Na tle uprzednich regulacji konstytucyjnych w sposób niejasny - i trzeba przyznać czysto deklaratywny - zapisano kwestie autonomii finansowej władz lokalnych i regionalnych. Według zapisów ustawy, ,jednostkom terytorialnym zapewnia się udział w dochodach publicznych odpowiednio do przypadających mu zadań”. Podobnie deklaratywnie zabrzmiała regulacja, iż „zmiany w zakresie zadań i kompetencji jednostek samorządowych następują wraz z odpowiednimi zmianami w podziale dochodów publicznych". Przywołane regulacje przypominają pewną deklarację władz państwa, ale bez wiążącego przymusu prawnego. Praktyka polityczna okresu po uchwaleniu konstytucji pokazuje, iż jest to zapis czysto blankietowy, często lekceważony przez administrację rządową. Bardziej precyzyjne regulacje odnoszące się do kwestii finansowych znajdujemy przy wymienianiu rodzajów dochodów samorządowych. Ustrojodawca polski wymienia w przedmiotowym kontekście dochody własne oraz dwa typy transferów $\mathrm{z}$ budżetu centralnego - w postaci subwencji ogólnych oraz dotacji celowych. Nie jest to zbiór zamknięty, bo pomija na przykład środki pochodzące z zagranicy, np. fundusze unijne, środki z Europejskiego Obszaru Gospodarczego. Konstytucja precyzuje, iż źródła dochodów samorządów terytorialnych określa akt normatywny rangi ustawowej, co ma zapewnić stabilność i przewidywalność rozwiązań prawnych w zakresie przedmiotowym (art. 167). Jak podkreślił Andrzej Bałaban, każda konstytucyjna dyspozycja wydania ustawy powinna być traktowana ,jako wiążące polecenie ustrojodawcy do możliwie szybkiego przygotowania i wydania ustawy regulującej przewidziane kategorie spraw" [Bałaban 2003: 27].

Jednocześnie wśród regulacji konstytucyjnych znajduje się zapis przekazujący władzom lokalnym prawo do ustalania wysokości podatków i opłat lokalnych, ale jedynie w zakresie określonym w akcie ustawowym. Należy zwrócić uwagę, iż powyższych regulacji nie spotykaliśmy we wcześniejszych polskich ustawach konstytucyjnych (art. 168).

Dwa artykuły konstytucji poświęcono mechanizmom sprawowania władzy w jednostkach samorządu lokalnego i regionalnego. Zgodnie z zasadą demokra- 
cji przedstawicielskiej, obejmującej zarówno szczebel centralny, jak i lokalny, obowiązuje model demokracji pośredniej. Ustrojodawca wymienia dwa organy władzy lokalnej i regionalnej - organ stanowiący oraz organ wykonawczy. W historii polskiego samorządu terytorialnego powyższy model władz samorządowych wprowadzono w 1933 r. na mocy tzw. ustawy scaleniowej. Warto podkreślić, iż ustrojodawca w odmienny sposób definiuje zasady wyborów organów stanowiących, a w odmienny organów wykonawczych. Pierwsze wybory definiowano przez tzw. przymiotniki wyborcze: powszechność, równość, bezpośredniość i tajność. Przy czym tajność odnosi się nie do wyborów, lecz do trybu głosowania. Jednocześnie konstytucja precyzuje, iż ważne kwestie wyborcze, takie jak: zasady i tryb zgłaszania kandydatów, przeprowadzania elekcji oraz ważności wyborów, określa akt normatywny rangi ustawowej. W inny sposób z kolei zdefiniowano elekcję organów wykonawczych. Ustawa stanowi, iż tryb i zasady wyborów i odwołania organów wykonawczych określają regulacje ustawowe. Polska praktyka ustrojowa po 1990 roku wyróżnia zarówno tryb wyborów pośrednich - lata 1990-2002, jak i elekcję powszechną - od 2002 roku. Podczas pierwszych trzech kadencji samorządu terytorialnego (z tego trzech szczebla gminnego) rada gminy wybierała kolegialny organ wykonawczy w postaci zarządu gminy. Od 2002 r. mieszkańcy wspólnot gminnych mają bezpośredni wpływ na wybór jednoosobowego organu wykonawczego - wójta, burmistrza, prezydenta miasta. Natomiast na szczeblu powiatowym i wojewódzkim elekcja pośrednia organów wykonawczych została utrzymana, choć w debacie publicznej pojawiają się postulaty wprowadzenia bezpośrednich wyborów starostów i marszałków województw [20 lat samorządu...; 25 lat samorządu...; XX lat samorzadu ...; Radomski 2017].

Jednocześnie konstytucja stanowi, iż ustrój wewnętrzny jednostek samorządu terytorialnego określają ich organy stanowiące, przy zastrzeżeniu, iż musi się on mieścić w granicach regulacji ustawowych. Jednakże należy się zastanowić, czy niezbędna jest konstytucjonalizacja aktu prawa miejscowego w postaci statutu jednostki samorządu (art. 169).

Z kolei w artykule 170 konstytucji znajdujemy wprowadzenie instytucji referendum lokalnego jako ważnej formy demokracji bezpośredniej. Ustawa stanowi, iż „członkowie wspólnoty samorządowej mogą decydować, w drodze referendum, o sprawach dotyczących tej wspólnoty, w tym o odwołaniu pochodzącego z wyborów bezpośrednich organu samorządu terytorialnego". Znajdujemy jednocześnie odesłanie do regulacji aktu normatywnego rangi ustawowej w zakresie zasad oraz trybu przeprowadzania referendów lokalnych. Warto wspomnieć, iż wcześniejsze polskie akty konstytucyjne nie przewidywały możliwości organizowania referendów na szczeblu lokalnym. Pierwszą regulację ustawową odnoszącą się do referendum gminnego uchwalono jeszcze podczas pierwszej kadencji władz gminnych 11 października 1991 roku. Po rozszerzeniu administracji samorządowej na szczeblu powiatowym i wojewódzkim w 1998 r. uchwalono nową ustawę wprowadzającą możliwość organizowania instytucji referendum również w powiatach i samorządowych województwach [Olejniczak-Szałowska 2002; Referendum lokalne ... 2002]. 
Artykuł 171 w sposób dość precyzyjny i dokładny określa organy, środki i kryteria nadzoru nad samorządami terytorialnymi. Ustrojodawca wymienia jedno kryterium nadzoru - legalność, czyli zgodność z obowiązującym prawem działań podejmowanych przez władze lokalne i regionalne. Do organów nadzoru konstytucja wymienia prezesa Rady Ministrów, wojewodów oraz - w zakresie kwestii finansowych - regionalne izby obrachunkowe. Warto wskazać, iż polskie konstytucje w odmienny sposób definiowały organy nadzorcze. Konstytucja kwietniowa wymieniała w przedmiotowym zakresie Radę Ministrów, wojewodów oraz starostów. Warto przypomnieć, iż do 1950 r. (a szczególnie do 1939 r.) posiadali oni odmienny status prawny - byli urzędnikami państwowymi powoływanymi przez ministra spraw wewnętrznych. Organy nadzoru finansowego w postaci Regionalnych Izb Obrachunkowych pojawiały się w polskim porządku prawnym w październiku 1992 r. i były wzorowane na rozwiązaniach francuskich [Dolnicki 2009: 387; Nadzór i kontrola ... 2013; Nadzór administracyjny... 2006; Storczyński 2006].

Konstytucja wymienia również procedurę rozwiązania organu stanowiącego (rady gminy, rady powiatu oraz sejmiku województwa) w przypadku rażącego naruszania przez ten organ konstytucji bądź regulacji ustawowych. Ponieważ rady samorządowe pochodzą z wyborów powszechnych, powyższą kompetencję przypisano Sejmowi, który działa w przedmiotowym zakresie na wniosek prezesa Rady Ministrów. Należy uznać powyższe rozwiązanie za zgodne z regułą, iż tylko organ pochodzący z elekcji powszechnej może rozwiązać - w szczególnych i ściśle określonych przypadkach - inny organ pochodzący z wyborów powszechnych. Należy podkreślić, iż konstytucja nie wymienia Sejmu wśród innych organów nadzorczych. W tym zakresie wspiera on działania premiera, może jego wniosek przyjąć lub odrzucić, a nie może w żadnym zakresie dokonywać modyfikacji (art. 171).

Ostatni artykuł w rozdziale 7 odnosi się do kwestii wolności stowarzyszania jednostek samorządu terytorialnego. Ustrojodawca zadeklarował, iż ,jednostki samorządu terytorialnego posiadają prawo zrzeszania się". Jest on doprecyzowany w następujący sposób: ,jednostka samorządu terytorialnego ma prawo przystępowania do międzynarodowych zrzeszeń społeczności lokalnych i regionalnych oraz współpracy ze społecznościami lokalnymi i regionalnymi innych państw". W przedmiocie zasad, na jakich jednostki samorządu terytorialnego mogą korzystać z wymienionych praw, konstytucja odsyła do regulacji ustawowych (art. 172).

\section{WNIOSKI}

Regulacje obecnej konstytucji odnoszące się do kwestii władz lokalnych należy uznać za bardzo szczegółowe, ale jednocześnie dość niespójne. Pierwszy czynnik jest rezultatem procesu demokratyzacji i decentralizacji władzy publicznej na początku III RP, gdy próbowano odcinać się zarówno od tradycji, jak i praktyki ustrojowej państwa polskiego po 1944 roku. Stąd wprowadzono szczegółowość rozwiązań konstytucyjnych, część z nich swobodnie nadawałaby 
się do regulacji ustawowych. Z kolei wymieniona już uprzednio niespójność zapisów konstytucyjnych jest rezultatem nierozstrzygniętych sporów pomiędzy ugrupowaniami parlamentarnymi odnoszącymi się do organizacji i zasad działania samorządów lokalnych i regionalnych. Ponieważ spór o model nie został do 1997 r. (momentu uchwalania konstytucji) rozstrzygnięty, wprowadzano „nie dość ostre" zapisy konstytucyjne bądź omijano niektóre kwestie. Obecnie po ponad 28 latach funkcjonowania samorządów gminnych oraz blisko dwóch dekadach administracji powiatowej i regionalnej być może zbliża się czas regulacji konstytucyjnych i pewnego porządkowania zaznaczonych uprzednio kwestii ustrojowo-administracyjnych. Jednakże pragnę zastrzec, iż powyższe zmiany powinny być dokonywane w bliskiej współpracy z organizacjami reprezentującymi samorządność terytorialną w Polsce.

Title: Constitutional Regulations Concerning Territorial Self-Governments Against the Background of Historical Approach in Poland

\begin{abstract}
The article analyzes current constitutional regulations pertaining to the issue of self-government authorities against the background of Polish constitutions. Showing the evolution of the Polish model of local self-government serves to present the process of institution formation and political practice regarding local government administration. At the same time, political and doctrinal disputes regarding the organization and principles of the Polish self-government were pointed out - especially this remark refers to the regional and poviat level.
\end{abstract}

Keywords: constitution, local self-government, decentralization, public administration

\title{
BIBLIOGRAFIA
}

1. 20 lat samorzadu terytorialnego w Polsce. Sukcesy, porażki, perspektywy, 2012, red. K. Mieczkowska-Czerniak, K. Radzik-Maruszak, Wyd. UMCS, Lublin.

2. XX lat samorzadu terytorialnego w Polsce. Doświadczenia-problemy-perspektywy, 2011, red. J. Kowalik, A. Bednarz, Adam Marszałek, Torun.

3. 25 lat samorzadu terytorialnego w Polsce - Bilans doświadczeń, 2016, red. S. Michałowski, M. Sidor, J. Wasil, Wyd. UMCS, Lublin.

4. Administracja publiczna, 2003, red. J. Hausner, PWN, Warszawa.

5. Ajnenkiel A., 2001, Konstytucje Polski w rozwoju dziejowym 1791-1997, Wyd. Rytm, Warszawa.

6. Bałaban A., 2003, Polskie problemy ustrojowe (Konstytucja, źródla prawa, samorząd terytorialny, prawa człowieka), Wyd. Zakamycze, Kraków.

7. Banaszak B., 2004, Porównawcze prawo konstytucyjne wspótczesnych państw demokratycznych, Wyd. Zakamycze, Kraków.

8. Barański M., Kantyka S., Kubas S., Kuś M., 2007, Samorząd terytorialny i wspólnoty lokalne, Wyd. Commandor, Warszawa.

9. Bujak Z., 2017, Konstytucja starsza niż myślisz, czyli o tym, co z historycznego dorobku państwa polskiego znajdziemy w naszej Konstytucji, Wyd. ZB, Milanówek. 
10. Bukowski Z., Jędrzejewski T., Rączka P., 2013, Ustrój samorządu terytorialnego, TNOiK, Toruń.

11. Dolnicki B., 1999, Samorząd terytorialny w polskich konstytucjach, [w:] W kręgu zagadnień konstytucyjnych. Profesorowi Eugeniuszowi Zwierzchowskiemu w darze, red. M. Kudej, Wyd. UŚ, Katowice.

12. Dolnicki B., 2009, Samorząd terytorialny, wyd. 4, Wolters Kluwer business, Warszawa.

13. Exposé premierów polskich. 1918-1997, 1998, oprac. B. Sygit, Zapolex Media, Toruń.

14. Garlicki L., 1997, Polskie prawo konstytucyjne. Zarys wykładu, cz. 1, Wyd. Liber, Warszawa.

15. Kallas M., 1990, Ustawa Konstytucyjna Księstwa Warszawskiego z 1807 r., [w:] Konstytucje Polski. Studia monograficzne z dziejów polskiego konstytucjonalizmu, t. 1, red. M. Kallas, PWN, Warszawa.

16. Kallas M., 2007, Historia ustroju Polski, PWN, Warszawa.

17. Konstytucja 3 maja 1791. Statut Zgromadzenia Przyjaciót Konstytucji, 1981, oprac. B. Leśnodorski, PWN, Warszawa.

18. Konstytucja Rzeczypospolitej Polskiej, 2010, Wydawnictwo Sejmowe, Warszawa.

19. Konstytucja. Wybór aktów prawnych do nauki prawa konstytucyjnego, 2011, wyd. 16, oprac. J. Mordwiłko, Liber, Warszawa.

20. Konstytucje Polski. Studia monograficzne z dziejów polskiego konstytucjonalizmu, 1990, t. 1-2, red. M. Kallas, PWN, Warszawa.

21. Konstytucje polskie 1918-1998, 1999, oprac. T. Mołdawa, Elipsa, Warszawa.

22. Krukowski S., 1990, Konstytucja Rzeczypospolitej Polskiej z 1921 r., [w:] Konstytucje Polski. Studia monograficzne z dziejów polskiego konstytucjonalizmu, t. 2, red. M. Kallas, PWN, Warszawa.

23. Leoński Z., 1999, Samorząd terytorialny w RP, wyd. 2, C.H. Beck, Warszawa.

24. Nadzór administracyjny: od prewencji do weryfikacji, 2006, red. C. Kociński, Wyd. Dolnośląskiej Szkoły Wyższej Służb Publicznych „Asesor”, Wrocław.

25. Nadzór i kontrola w systemie wykonywania administracji publicznej, 2013, red. M. Czuryk, M. Karpiniuk, Wyd. Erida, Warszawa.

26. Ochendowski E., 1994, Prawo administracyjne, Wyd. COMER, Toruń.

27. Olejniczak-Szałowska E., 2002, Referendum lokalne w świetle ustawodawstwa polskiego, Wyd. Difin, Warszawa.

28. Piasecki A.K., 2009, Samorząd terytorialny $i$ wspólnoty lokalne, PWN, Warszawa.

29. Popławska E., 1998, Zasada pomocniczości (subsydiarności), [w:] Zasady podstawowe polskiej konstytucji, red. W. Sokolewicz, Wydawnictwo Sejmowe, Warszawa.

30. Powiat, 2001, red. J. Boć, Kolonia Limited, Wrocław.

31. Radomski G., 2017, Spory o samorząd terytorialny w polskiej myśli politycznej po 1989 roku, Wyd. UMK, Toruń 2017.

32. Referendum lokalne; praktyczny komentarz do ustawy, 2002, red. D. Dąbkowski, Ł. Zając, Zachodnie Centrum Organizacji, Zielona Góra.

33. Regulski J., 2000, Samorzad III Rzeczypospolitej. Koncepcje i realizacja, PWN, Warszawa.

34. Regulski J., Kulesza M., 2009, Droga do samorzadu. Od pierwszych koncepcji do inicjatywy Senatu (1981-1989), Wolters Kluwer business, Warszawa.

35. Rola samorzadu terytorialnego w modernizacji Polski, 2010, red. M. Barański, A. Czyż, S. Kubas, Wyd. „Śląsk”, Katowice. 
36. Samorząd terytorialny i rozwój lokalny, 1992, red. A. Piekara, Z. Niewiadomski, Centrum Studiów Samorządu Terytorialnego UW, Warszawa.

37. Samorząd terytorialny w Polsce w latach 1918-1939. Wybór materiatów źródłowych, 2000, oprac. R. Szwed, Wyd. Wyższej Szkoły Pedagogicznej w Częstochowie, Częstochowa.

38. Samorzad w Polsce. Istota, formy, zadania, 2004, red. S. Wykrętowicz, Wyd. Wyższej Szkoły Bankowej, Poznań.

39. Storczyński J., 2006, Nadzór regionalnych izb obrachunkowych nad samorzadem terytorialnym, „Branta”, Bydgoszcz-Chorzów.

40. Szcząska Z., 1990, Ustawa Rządowa z 1791 r., [w:] Konstytucje Polski. Studia monograficzne z dziejów polskiego konstytucjonalizmu, t. 2, red. M. Kallas, PWN, Warszawa.

41. Szreniawski J., 1994, Prawo administracyjne. Część ogólna, Wyd. UMCS, Lublin.

42. W kręgu zagadnień konstytucyjnych. Profesorowi Eugeniuszowi Zwierzchowskiemu w darze, 1999, red. M. Kudej, Wyd. UŚ, Katowice.

43. Witkowski W., 2007, Historia administracji w Polsce. 1794-1989, PWN, Warszawa.

44. Wójcik S., 1999, Samorząd terytorialny w Polsce w XX wieku. Myśl samorządowa. Historia i współczesność, Wyd. KUL, Lublin.

45. Zasady podstawowe polskiej konstytucji, 1998, red. W. Sokolewicz, Wydawnictwo Sejmowe, Warszawa.

46. Zawadzka B., 1998, Zasada udziału samorzadu w sprawowaniu władzy, [w:] Zasady podstawowe polskiej konstytucji, red. W. Sokolewicz, Wydawnictwo Sejmowe, Warszawa.

47. Zieliński E., 2013, Administracja rzadowa i samorządowa, Aspra-JR, Warszawa. 